Article

\title{
Animal Welfare Programs in Germany-An Empirical Study on the Attitudes of Pig Farmers
}

\author{
Sirkka Schukat *, Louisa von Plettenberg and Heinke Heise \\ Department of Agricultural Economics and Rural Development, University of Göttingen, \\ 37073 Göttingen, Germany; louisa.plettenberg@uni-goettingen.de (L.v.P.); \\ heinke.heise@agr.uni-goettingen.de (H.H.) \\ * Correspondence: sirkka.schukat@uni-goettingen.de
}

Received: 30 October 2020; Accepted: 6 December 2020; Published: 8 December 2020

\begin{abstract}
In Europe, there is ongoing social criticism of conventional pig farming and demands for higher farm animal welfare standards. This applies primarily to products from pig production, as consumers criticize, among other things, the animals' housing conditions, tail docking, neutering, or keeping them on slatted floors. Various animal welfare programs have tried to meet the consumers' demands. Pig farmers are directly involved in the production process and are therefore key stakeholders for the successful implementation of animal welfare programs such as the German Initiative Animal Welfare. The Initiative Animal Welfare was founded in 2015 and serves as an example in this study, as it has been established for two rounds and involves high numbers of participants. However, little is known about the attitudes of pig farmers towards this specific animal welfare program. Thus, the aim of this study is to investigate these attitudes towards animal welfare programs using the example of German pig producers and identify group differences. Based on an online survey of German conventional pig farmers, four clusters were formed which differ in their attitude to the Initiative Animal Welfare. Overall, all farmers, regardless of the cluster, feel publicly pressured by politics and the media. In addition, all farmers are skeptical about the effort involved in participating in the Initiative Animal Welfare (IAW), especially with regard to the additional documentation requirements and unannounced controls. The findings can provide guidance for the design of animal welfare programs taking into account the needs of farmers.
\end{abstract}

Keywords: farmers' attitudes; cluster analysis; farm animal welfare; pig production

\section{Introduction}

The image of conventional livestock farming has been suffering for some time. Due to the constant structural changes and the progressive intensification of agricultural production processes, conventional livestock farming is increasingly subject to public criticism. Food crises and scandals as well as a changed perception of agriculture by broad sections of society have had a major impact on public debate [1,2]. As a result, there is a strong aversion to the current systems of livestock farming, especially for pigs and poultry [3,4]. This increases sensitivity to meat production and processing and to requirements aimed at improving the level of farm animal welfare standards [5-8]. Eventually, the meat industry and other stakeholders have expanded the meat market to include a new segment, so-called animal welfare products, to close the gap between heavily criticized conventional products and organically produced and very high-priced meat products [9-11]. One possibility for farmers to provide higher farm animal welfare standards is therefore to participate in specific animal welfare programs (AWPs) or programs with higher quality and sustainability standards [12,13].

Germany is not only one of the largest meat producers in the world, but with a net output of $5,348,000$ tons of pork and a self-sufficiency rate of 119 percent in 2018, it is also considered one of the 
key players on the international market [14]. For this reason, it is assumed that examples and results from Germany can also be relevant and informative on an international level. In Germany, for example, the Initiative Animal Welfare (IAW) was founded in 2015. It aims at a general improvement of farm animal welfare in German poultry and pig production, whereas farmers are compensated by the food retail sector itself for implementing additional farm animal welfare criteria. Current consumer surveys indicate that the IAW concept is rated from "good" to "very good" by 93 percent of those surveyed [15]. In Germany, 10.7 million fattening pigs are kept in accordance with IAW criteria to date, which corresponds to approximately 25 percent of fattening pigs produced in Germany. Participating food retailers, e.g., Edeka, Rewe, Lidl, and Aldi, pay an additional sum of 6.25 cents per kilo of pork or poultry meat sold to the IAW, thus contributing to the costs incurred by farmers in implementing the additional farm animal welfare criteria [16]. Thereby, the financing is independent of the purchasing behavior of the consumers. Since 2020, a total number of 4200 pig farmers have participated in the IAW [17].

In general, there are both mandatory and eligible criteria for fattening pigs, sows, and piglets. For the implementation of the basic criteria, a basic contribution of $€ 500$ per farm is paid. For providing the mandatory criteria, the farmers receive $€ 3.30$ per pig for the implementation of the mandatory criteria, whereas eligible criteria can also be applied voluntarily. In order to fit the participation requirements of the IAW, all basic criteria must be fulfilled. These include animal monitoring, handling of diseased and injured animals, as well as hygiene and storage of animal feed. Furthermore, stable climate and drinking water controls must be executed by IAW auditors. Climate controls include a functional test of the technology and a sensory pen climate examination. In addition, pens must have access to daylight. Mandatory criteria include "additional 10 percent space" and "organic manipulable material" which could, for example, constitute wood or straw for the animals' entertainment. If the farm chooses an eligibility criterion like, for example, "additional 20 percent space", compensation is granted in addition to remuneration for compliance with the mandatory criterion "additional 10 percent space". The maximum fee is $€ 5.10$ per pig, which means eligible criteria cannot exceed $€ 1.80$ per pig [15]. What makes the IAW unique are the relatively easy to implement farm animal welfare criteria as well as the guaranteed and fixed remuneration of the pig farmers. These characteristics and the fact that it is the most popular AWP in Germany distinguish the IAW from other AWPs.

Farm animal welfare depends to a considerable extent on farmers' attitudes, acceptance, and willingness to implement measures to improve livestock conditions on their farms [18]. Without understanding of farmers' decisions for or against certain measures, farm animal welfare can hardly be improved [19]. To date, some studies have been investigating the attitudes of German pig farmers towards higher farm animal welfare standards and their willingness to participate in AWPs [20], but not with main focus on the IAW. Furthermore, previous studies have shown that farmers cannot usually be seen as a homogeneous group in terms of their attitudes [21], so it must be assumed that this is also true with regard to farmers' attitudes towards the IAW. For this reason and to close this research gap, a cluster analysis was chosen for this article in order to find potential target groups for IAW participation and to characterize them more precisely so that target group-specific recommendations for action can be derived. The results have important implications for farmer and stakeholder management both nationally and internationally, resulting in opportunities to tailor AWPs to farmers' needs and wishes. In the following, the applied methodology is presented. This is followed by the presentation of the results, discussion, and final conclusion.

\section{Materials and Methods}

\subsection{Study Design}

For this article, a survey was analyzed in which 219 conventional pig farmers in Germany participated from February 2018 to June 2018. The survey was based on an anonymous and standardized online questionnaire. The questionnaire itself was pre-tested for one week by ten experts from agro- 
economic research and pig farmers. Subsequently, it was distributed via websites of leading German farm management magazines and the Association of Pig Farmers in Germany. The magazines most read in agricultural practice were asked to distribute the survey. The questionnaire itself was preceded by a brief description of the background and aims of the study. To further spread the survey, private networks and social media were used. The survey was further distributed via the IAW's mailing list. Qualitative interviews among 45 pig farmers were conducted beforehand. Due to the results of the qualitative interviews, the survey was based on the extended "unified theory of acceptance and use of technology" model [22]. With its key constructs being performance expectancy, effort expectancy, social influence, facilitating conditions, hedonic motivation, price value, and habit, it provides a conceptual framework for analyzing decision makers' intention to use or not to use a certain technology or system. Further, it has been applied for some time to investigate acceptance issues for technologies or systems within agriculture [23].

The survey questions mainly consisted of closed questions which were derived from scientific literature [18]. Further, it was divided into two parts. In part A, participating farmers were asked about their socio-demographic and farm characteristics, for example, age, gender, agricultural education, work experience, farm size, pig housing conditions, and their IAW participation. Nominally scaled questions were used to inquire about operational and socio-demographic and farm characteristics. Part B consisted of 70 different statements that were used to determine farmers' attitudes towards their IAW participation. The respondents were asked to rate predefined statements on the basis of five-point Likert scales from -2 meaning "I totally disagree" to +2 meaning "I totally agree". The statements should have been answered by both IAW participants and non-participants.

\subsection{Statistical Analysis}

The analysis was carried out using IBM SPSS Statistics 25 for MacOS. To obtain an overview of the sample, socio-demographic and farm characteristics were first analyzed using univariate methods. Next, an exploratory factor analysis was performed to combine a large number of items into a smaller number of factors, which allows a simplified interpretation of farmers' attitudes towards the IAW. For this article, a principal component analysis using varimax rotation method and Kaiser Normalization was applied. Varimax rotation was applied because the variance of squared charges in this rotation reaches the maximum value and thus facilitated interpretation [24]. The factor analysis included most Likert scaled items about the IAW with regard to farm animal welfare, economic risks, and effects of higher farm animal welfare standards and farmers' willingness to improve farm animal welfare on their farms. The selected number of items was checked for suitability for factor analysis. For this purpose, the Kaiser Meyer Olkin Criteria (KMO) and the "measure of sampling adequacy" (MSA) were used. If the KMO/MSA is $<0.5$, it is "miserable", and a factor analysis should not be performed [25]. In this study, a value of 0.872 was determined, which is classified as "good" [26]. Another quality test criterion is the Bartlett test for sphericity, which examines the null hypothesis so that the initial variables from the survey population are present in uncorrelated form [26]. In this study, Bartlett's significance is at a value of $p=0.000$, which is highly significant because it allows the null hypothesis to be discarded and therefore there is correlation between the variables. Furthermore, only those factors are extracted that have a value greater than 1 (assumption of the principal component analysis). Here, the factor analysis explained 69.78 percent of the total variance. Finally, six factors including 28 items were identified. A reliability analysis provided information about the internal consistency of the factors. Cronbach's Alpha value was chosen to measure the consistency. All of the six factors show a valid internal consistency $[27,28]$.

A hierarchical cluster analysis was performed to classify farmers into different segments in terms of their attitude towards the IAW. A hierarchical cluster analysis was chosen because of the relatively small sample size. For this purpose, the factors previously built up were used to characterize the clusters. This kind of cluster analysis is used to form homogeneous groups out of a heterogeneous population $[26,29]$. The cluster analysis was divided into three steps. First, the single-linkage method 
was used to remove outliers. The objects with the smallest distances were combined with another. Next, the optimal number of clusters was determined using Ward's method. In this article, four clusters could be determined. The dendrogram, a screen plot, and the elbow criterion were used as decision support for the optimal number of clusters [26].

Eventually, a k-Means clustering was used to optimize the results of Ward's method. A discriminant analysis was performed to verify the results. In this study, 98.6 percent of the original cases were correctly classified $[26,28]$. Further results of the discriminant analysis (eigenvalues and Wilks lambda) also demonstrate that the results of the cluster analysis are of high quality. Wilks-Lambda is a significance test that confirms a significant difference between the groups identified in this study. Moreover, the eigenvalue was higher than one and there were significant differences $(p<0.000)$ between the cluster-forming factors [27]. For a detailed characterization of the generated clusters, Tamhane T2 post hoc multiple comparison test was used, which showed significant differences between the clusters. Tamhane T2 test is based on the assumption that groups may show different variances. For a more detailed description and to test significant differences between the clusters, a univariate ANOVA and a cross-table were used [28]. Furthermore, the clusters were analyzed with regard to socio-demographic and farm characteristics.

\section{Results}

\subsection{Sample Description}

After data cleansing, 219 complete data sets were available for the analysis. Farmers who took part in the survey are on average 45 years old, and 92.2 percent of them are male. In Germany, the average age of farmers is 34 years and 36 percent of all workers in agriculture are female [30]. On average, they are very well educated, as 33.8 percent are university graduates. In comparison, the German national average of famers holding a university degree is only 12 percent [30]. The majority of participants come from North Rhine-Westphalia (32.4 percent) and Lower Saxony (32 percent). According to the agricultural census of 2016, these federal states have the highest number of pigs kept for farming purposes with 26.3 percent in North Rhine-Westphalia and 31.6 percent in Lower Saxony [31]. The average farm size is 195.89 hectares, which is significantly higher than the average number of hectares per farm in Germany [32]. A figure of 83.6 percent of the respondents are farm managers; 11.4 percent are farm successors, whereas in total, about 11 percent of those employed in agriculture in Germany are farm managers [32]. In addition, 94.1 percent of the farms are managed as main occupation, whereby in Germany, 45.3 percent of farms are run as a main occupation [32]. On average, 2026 fattening pigs $(n=219)$ are kept on farms. A figure of 68 percent of the respondents were taking part in the IAW at the time of the survey. In Germany, 6.44 percent of agricultural businesses take part in the IAW [32]. Due to the small sample size and the participants' farm characteristics, this sample cannot be considered representative for all German pig farmers. Although the sample deviates from the German population and thus a certain result uncertainty arises, it can be an interesting exploratory sample for large, full-time pig farmers.

\subsection{Results of the Factor Analysis}

In order to reduce the data complexity, an exploratory factor analysis was conducted and the most important factors for farmers' attitudes towards the IAW were captured. The final factor solution included six factors with 28 variables (Table 1). The first factor, "economic benefit", describes the assessment of farmers' financial advantages resulting from IAW participation and contains seven statements (Cronbach's Alpha: 0.911). In particular, these statements are aimed at ascertaining whether farmers are of the opinion that implementation of farm animal welfare measures under IAW is appropriately remunerated. They include farmers' attitudes towards perception of remuneration, cost-benefit ratio, and possible income stabilization in an event of poor pig prices. The second factor, "trust in the IAW," covers farmers' attitudes with a direct connection to the IAW and contains six 
statements (Cronbach's Alpha: 0.884). It combines statements about perceived intentions of the IAW with regard to consideration of farmers' wishes and needs in the AWP design, additional documentation requirements, and payments. The third factor, "animal benefit", (Cronbach's Alpha: 0.907) describes advantages that IAW participation provides for the animals. The five statements relate to the improvements perceived by farmers in housing conditions, farm animal welfare, health, and performance of the animals. The fourth factor, "effort", combines six statements about expenditures incurred by IAW participation (Cronbach's Alpha: 0.851). The statements include perceived attitudes towards investment costs, labor costs, certification costs, and effort required for controls and documentation. The fifth factor, "unannounced controls", summarizes two variables about farmers' attitudes towards unannounced controls that are performed as part of their IAW participation (Cronbach's Alpha: 0.851). It takes into account statements about the risk of being exposed to additional stress due to controls. The sixth factor, "perceived public pressure", combines two statements about pressure on farmers perceived by politics and the media (Cronbach's Alpha: 0.801). The factors represent the individualized roles of each of the benefits and costs involved in IAW participation, including financial and personal contributions as well as monetary, personal, and time-related costs.

Table 1. Results of the factor analysis.

\begin{tabular}{|c|c|c|c|}
\hline Factor and Statements & Factor Load & $\mu$ & $\sigma$ \\
\hline \multicolumn{4}{|l|}{ Factor 1: Economic benefit (Cronbach's Alpha: 0.911) } \\
\hline Participation in the IAW is financially worthwhile. & 0.828 & -0.16 & 1.023 \\
\hline $\begin{array}{l}\text { The additional time required for participation in the IAW will be } \\
\text { remunerated appropriately. }\end{array}$ & 0.791 & -024 & 1.040 \\
\hline $\begin{array}{l}\text { The participation in the IAW is characterized by a good } \\
\text { cost-benefit ratio. }\end{array}$ & 0.746 & -0.33 & 0.954 \\
\hline $\begin{array}{c}\text { The animal welfare criteria of the IAW are appropriately } \\
\text { remunerated. }\end{array}$ & 0.724 & -0.23 & 1.039 \\
\hline $\begin{array}{l}\text { The participation in the IAW offers additional financial benefits } \\
\text { for the farm. }\end{array}$ & 0.698 & 0.53 & 1.015 \\
\hline $\begin{array}{l}\text { The additional remuneration by the IAW stabilizes the income } \\
\text { situation of the farm in case of a bad pig price. }\end{array}$ & 0.668 & 0.36 & 1.142 \\
\hline $\begin{array}{l}\text { The additional stress associated with participation in the IAW will } \\
\text { be adequately compensated. }\end{array}$ & 0.660 & -0.51 & -0.974 \\
\hline \multicolumn{4}{|l|}{ Factor 2: Trust in the IAW (Cronbach's Alpha: 0.884) } \\
\hline $\begin{array}{l}\text { The IAW makes every effort to take the needs and wishes of } \\
\text { farmers into account in the remuneration of the various animal } \\
\text { welfare criteria. }\end{array}$ & 0.833 & -0.33 & 0.954 \\
\hline $\begin{array}{l}\text { The IAW makes every effort to consider the needs and wishes of } \\
\text { farmers when designing the program. }\end{array}$ & 0.815 & -0.19 & 0.919 \\
\hline $\begin{array}{l}\text { The IAW makes every effort to take the needs and wishes of } \\
\text { farmers into account in the additional documentation. }\end{array}$ & 0.802 & -0.35 & 0.942 \\
\hline $\begin{array}{c}\text { The IAW would never knowingly do anything detrimental to } \\
\text { participating farmers. }\end{array}$ & 0.740 & -0.10 & 1.064 \\
\hline $\begin{array}{l}\text { The IAW makes every effort to take the needs and wishes of } \\
\text { farmers into account when paying animal welfare remuneration. }\end{array}$ & 0.696 & -0.10 & 0.993 \\
\hline $\begin{array}{c}\text { The IAW makes every effort to take the needs and wishes of } \\
\text { farmers into account during controls. }\end{array}$ & 0.674 & -0.27 & 0.965 \\
\hline \multicolumn{4}{|l|}{ Factor 3: Animal benefit (Cronbach's Alpha: 0.907) } \\
\hline $\begin{array}{l}\text { Participation in the IAW improves the housing conditions of } \\
\text { the animals. }\end{array}$ & 0.884 & 0.59 & 0.960 \\
\hline Participation in the IAW improves the welfare of the animals. & 0.855 & 0.48 & 1.051 \\
\hline $\begin{array}{c}\text { Participation in the IAW improves the possibilities to practice } \\
\text { typical behavior of the animals. }\end{array}$ & 0.804 & 0.32 & 0.928 \\
\hline
\end{tabular}


Table 1. Cont.

\begin{tabular}{|c|c|c|c|}
\hline Factor and Statements & Factor Load & $\mu$ & $\sigma$ \\
\hline Participation in the IAW improves the health of the animals. & 0.800 & 0.17 & 1.065 \\
\hline Participation in the IAW improves the performance of the animals. & 0.756 & 0.10 & 1.013 \\
\hline \multicolumn{4}{|l|}{ Factor 4: Effort (Cronbach's Alpha: 0.851) } \\
\hline $\begin{array}{l}\text { Participation in the IAW involves high investments for the } \\
\text { implementation of the various animal welfare criteria. }\end{array}$ & 0.884 & 0.67 & 0.978 \\
\hline $\begin{array}{c}\text { Participation in the IAW is associated with high additional } \\
\text { labor costs. }\end{array}$ & 0.855 & 0.32 & 1.128 \\
\hline $\begin{array}{l}\text { Participation in the IAW is associated with high additional costs } \\
\text { for the certification. }\end{array}$ & 0.804 & 0.69 & 0.983 \\
\hline $\begin{array}{l}\text { Participation in the IAW means a high expenditure of time for the } \\
\text { daily work in the stable. }\end{array}$ & 0.800 & 0.52 & 1.068 \\
\hline $\begin{array}{c}\text { Participation in the IAW means a high expenditure of time for } \\
\text { the documentation. }\end{array}$ & 0.756 & 1.05 & 0.912 \\
\hline Participation in the IAW involves time-consuming controls. & 0.647 & 0.99 & 0.948 \\
\hline \multicolumn{4}{|l|}{ Factor 5: Unannounced controls (Cronbach's Alpha: 0.851) } \\
\hline $\begin{array}{c}\text { Participation in the IAW causes additional stress due to } \\
\text { unannounced controls. }\end{array}$ & 0.835 & 0.91 & 1.121 \\
\hline $\begin{array}{l}\text { Participation in the IAW bears the risk of being exposed to } \\
\text { additional stress because unannounced controls must always } \\
\text { be expected. }\end{array}$ & 0.827 & 0.90 & 1.044 \\
\hline \multicolumn{4}{|l|}{ Factor 6: Perceived public pressure (Cronbach's Alpha: 0.801) } \\
\hline $\begin{array}{l}\text { I feel pressure from politicians to improve the housing conditions } \\
\text { in my pigsty. }\end{array}$ & 0.877 & 0.64 & 1.071 \\
\hline $\begin{array}{l}\text { I feel pressure from the media to improve the housing conditions } \\
\text { in my pigsty. }\end{array}$ & 0.867 & 0.88 & 1.149 \\
\hline
\end{tabular}

The tests performed to examine the quality of factor analysis showed that all factors meet the common requirements. The factor analysis explained 69.78 percent of the total variance among the 24 variables. Since KMO/MSA is relatively high at 0.872 , these variables are well suited for the factor analysis. The factors identified were adopted as cluster-forming variables to define groups for IAW participation.

\subsection{Results of the Cluster Analysis}

A cluster analysis was performed on the basis of the factors detected. The aim of the cluster analysis was to classify farmers into groups according to their IAW attitudes. Table 2 presents the results of the cluster analysis, mean values of the cluster-forming factors, and the underlying variables.

Table 2. Results of the cluster analysis.

\begin{tabular}{ccccc}
\hline Factor and Statements & $\begin{array}{c}\text { Cluster D } \\
(n=52)\end{array}$ & $\begin{array}{c}\text { Cluster A } \\
(n=55)\end{array}$ & $\begin{array}{c}\text { Cluster B } \\
(n=56)\end{array}$ & $\begin{array}{c}\text { Cluster C } \\
(n=53)\end{array}$ \\
\hline Economic benefit ${ }^{* * *}$ & $-0.41^{\mathrm{bc}}$ & $-0.78^{\mathrm{bc}}$ & $0.92^{\mathrm{acd}}$ & $0.21^{\mathrm{abd}}$ \\
$(0.712)$ & $(0.709)$ \\
\hline Participation in the IAW is financially worthwhile. ${ }^{* * *}$ & $-0.73^{\mathrm{bc}}$ & $-0.75^{\mathrm{bc}}$ & $0.54^{\mathrm{ad}}$ & $0.26^{\mathrm{ad}}$ \\
& $(0.843)$ & $(0.886)$ & $(0.738)$ & $(0.902)$ \\
\hline The additional time required for participation in the & $-1.02^{\mathrm{bc}}$ & $-0.69^{\mathrm{bc}}$ & $0.52^{\mathrm{ad}}$ & $0.17^{\mathrm{ad}}$ \\
IAW is remunerated appropriately. $^{* * *}$ & $(0.727)$ & $(0.879)$ & $(0.809)$ & $(0.935)$ \\
\hline Participation in the IAW is characterized by a good & $-0.94^{\mathrm{bc}}$ & $-0.82^{\mathrm{bc}}$ & $0.38^{\mathrm{ad}}$ & $0.04^{\mathrm{ad}}$ \\
cost-benefit ratio. ${ }^{* * *}$ & $(0.669)$ & $(0.976)$ & $(0.776)$ & $(0.831)$ \\
\hline
\end{tabular}


Table 2. Cont.

\begin{tabular}{|c|c|c|c|c|}
\hline Factor and Statements & $\begin{array}{l}\text { Cluster D } \\
(n=52)\end{array}$ & $\begin{array}{c}\text { Cluster A } \\
(n=55)\end{array}$ & $\begin{array}{l}\text { Cluster B } \\
(n=56)\end{array}$ & $\begin{array}{c}\text { Cluster C } \\
(n=53)\end{array}$ \\
\hline $\begin{array}{l}\text { The animal welfare criteria of the IAW are appropriately } \\
\text { remunerated. }\end{array}$ & $\begin{array}{l}-0.96^{\mathrm{bc}} \\
(0.766)\end{array}$ & $\begin{array}{l}-0.62^{b c} \\
(0.892)\end{array}$ & $\begin{array}{l}0.50 \text { ad } \\
(0.831)\end{array}$ & $\begin{array}{l}0.06^{\mathrm{ad}} \\
(0.969)\end{array}$ \\
\hline $\begin{array}{l}\text { Participation in the IAW offers additional financial } \\
\text { benefits for the farm. }\end{array}$ & $\begin{array}{l}0.17^{b c} \\
(0.879)\end{array}$ & $\begin{array}{l}-0.15^{b c} \\
(0.848)\end{array}$ & $\begin{array}{l}1.07^{\text {ad }} \\
(0.912)\end{array}$ & $\begin{array}{l}0.96^{\text {ad }} \\
(0.831)\end{array}$ \\
\hline $\begin{array}{l}\text { The additional remuneration by the IAW stabilizes the } \\
\text { income situation of the farm in case of a bad pig price. }{ }^{* * *}\end{array}$ & $\begin{array}{l}-0.02^{b c} \\
(1.075)\end{array}$ & $\begin{array}{l}-0.38^{\mathrm{bc}} \\
(1.063)\end{array}$ & $\begin{array}{l}1.07^{\text {ad }} \\
(0.783)\end{array}$ & $\begin{array}{l}0.74^{\text {ad }} \\
(0.964)\end{array}$ \\
\hline $\begin{array}{l}\text { The additional stress associated with participation in the } \\
\text { IAW is adequately compensated. }{ }^{* * *}\end{array}$ & $\begin{array}{l}-1.12^{b c} \\
(0.732)\end{array}$ & $\begin{array}{l}-0.95^{b c} \\
(0.756)\end{array}$ & $\begin{array}{l}-0.20^{\mathrm{ad}} \\
(0.999)\end{array}$ & $\begin{array}{l}0.17^{\mathrm{ad}} \\
(0.778)\end{array}$ \\
\hline Trust in the IAW ** & $\begin{array}{l}-0.33^{\text {ac }} \\
(0.848)\end{array}$ & $\begin{array}{c}0.27^{\mathrm{d}} \\
(1.080)\end{array}$ & $\begin{array}{c}-0.14 \\
(0.965)\end{array}$ & $\begin{array}{l}0.15^{\mathrm{d}} \\
(0.709)\end{array}$ \\
\hline $\begin{array}{l}\text { The IAW makes every effort to take the needs and } \\
\text { wishes of farmers into account in the remuneration of } \\
\text { the various animal welfare criteria. }{ }^{* * *}\end{array}$ & $\begin{array}{l}-0.79 \text { abc } \\
(0.825)\end{array}$ & $\begin{array}{l}-0.31^{\mathrm{d}} \\
(0.979)\end{array}$ & $\begin{array}{l}-0.23^{\mathrm{d}} \\
(0.914)\end{array}$ & $\begin{array}{l}-0.06^{\mathrm{d}} \\
(0.908)\end{array}$ \\
\hline $\begin{array}{l}\text { The IAW makes every effort to consider the needs and } \\
\text { wishes of farmers when designing the program. }\end{array}$ & $\begin{array}{l}-0.54^{\mathrm{c}} \\
(0.851)\end{array}$ & $\begin{array}{l}-0.20 \\
(0.970)\end{array}$ & $\begin{array}{c}-0.16 \\
(0.781)\end{array}$ & $\begin{array}{c}0.09^{\mathrm{d}} \\
(0.946)\end{array}$ \\
\hline $\begin{array}{l}\text { The IAW makes every effort to take the needs and } \\
\text { wishes of farmers into account in the } \\
\text { additional documentation. * }\end{array}$ & $\begin{array}{l}-0.67^{\mathrm{c}} \\
(0.834)\end{array}$ & $\begin{array}{c}-0.29 \\
(0.994)\end{array}$ & $\begin{array}{c}-0.29 \\
(0.986)\end{array}$ & $\begin{array}{l}-0.19^{\mathrm{d}} \\
(0.856)\end{array}$ \\
\hline $\begin{array}{l}\text { The IAW would never knowingly do anything } \\
\text { detrimental to participating farmers. }\end{array}$ & $\begin{array}{l}-0.42^{\mathrm{c}} \\
(0.997)\end{array}$ & $\begin{array}{c}-0.13 \\
(1.171)\end{array}$ & $\begin{array}{c}-0.09 \\
(1.100)\end{array}$ & $\begin{array}{l}0.21^{\mathrm{d}} \\
(0.863)\end{array}$ \\
\hline $\begin{array}{l}\text { The IAW makes every effort to take the needs and } \\
\text { wishes of farmers into account when paying animal } \\
\text { welfare remuneration. }\end{array}$ & $\begin{array}{l}-0.54^{\mathrm{ac}} \\
(0.985)\end{array}$ & $\begin{array}{c}0.02^{\mathrm{d}} \\
(1.027)\end{array}$ & $\begin{array}{c}-0.12 \\
(1.046)\end{array}$ & $\begin{array}{c}0.21^{\mathrm{d}} \\
(0.885)\end{array}$ \\
\hline $\begin{array}{l}\text { The IAW makes every effort to take the needs and } \\
\text { wishes of farmers into account during controls.* }\end{array}$ & $\begin{array}{l}-0.48^{\mathrm{a}} \\
(0.896)\end{array}$ & $\begin{array}{l}-0.40^{\mathrm{c}} \\
(1.011)\end{array}$ & $\begin{array}{c}-0.34 \\
(1.014)\end{array}$ & $\begin{array}{l}0.09 \text { ad } \\
(0.815)\end{array}$ \\
\hline Animal benefit ${ }^{* * *}$ & $\begin{array}{l}-0.12^{\mathrm{c}} \\
(0.735)\end{array}$ & $\begin{array}{l}-0.49^{b c} \\
(0.948)\end{array}$ & $\begin{array}{c}0.24^{\mathrm{a}} \\
(0.896)\end{array}$ & $\begin{array}{l}0.46^{\text {ad }} \\
(0.953)\end{array}$ \\
\hline $\begin{array}{l}\text { Participation in the IAW improves the housing } \\
\text { conditions of the animals. }\end{array}$ & $\begin{array}{l}0.40^{\mathrm{bc}} \\
(0.721)\end{array}$ & $\begin{array}{l}0.13^{b c} \\
(1.001)\end{array}$ & $\begin{array}{l}0.91 \text { ad } \\
(0.880)\end{array}$ & $\begin{array}{l}0.98 \text { ad } \\
(0.820)\end{array}$ \\
\hline $\begin{array}{l}\text { Participation in the IAW improves the welfare of } \\
\text { the animals. }\end{array}$ & $\begin{array}{l}0.10^{\mathrm{bc}} \\
(0.975)\end{array}$ & $\begin{array}{l}-0.07^{\mathrm{bc}} \\
(1.016)\end{array}$ & $\begin{array}{l}0.96^{\mathrm{ad}} \\
(0.808)\end{array}$ & $\begin{array}{l}1.00 \mathrm{ad} \\
(0.809)\end{array}$ \\
\hline $\begin{array}{l}\text { Participation in the IAW improves the possibilities to } \\
\text { practice typical behavior of the animals. }\end{array}$ & $\begin{array}{l}0.13^{b c} \\
(0.742)\end{array}$ & $\begin{array}{l}-0.04^{b c} \\
(0.744)\end{array}$ & $\begin{array}{l}0.63^{\text {ad }} \\
(0.945)\end{array}$ & $\begin{array}{l}0.60 \text { ad } \\
(0.968)\end{array}$ \\
\hline $\begin{array}{c}\text { Participation in the IAW improves the health of } \\
\text { the animals. } * * *\end{array}$ & $\begin{array}{l}-0.08^{b c} \\
(0.947)\end{array}$ & $\begin{array}{l}-0.40^{b c} \\
(0.894)\end{array}$ & $\begin{array}{l}0.54^{\mathrm{ad}} \\
(0.808)\end{array}$ & $\begin{array}{l}0.68^{\text {ad }} \\
(1.140)\end{array}$ \\
\hline $\begin{array}{l}\text { Participation in the IAW improves the performance of } \\
\text { the animals. }\end{array}$ & $\begin{array}{l}-0.12^{b c} \\
(0.704)\end{array}$ & $\begin{array}{l}-0.49^{b c} \\
(0.814)\end{array}$ & $\begin{array}{l}0.41^{\text {ad }} \\
(1.075)\end{array}$ & $\begin{array}{l}0.64^{\text {ad }} \\
(0.922)\end{array}$ \\
\hline Effort $* * *$ & $\begin{array}{l}0.87^{\mathrm{abc}} \\
(0.543)\end{array}$ & $\begin{array}{c}-0.59 \text { ad } \\
(0.954)\end{array}$ & $\begin{array}{l}0.05^{\mathrm{ad}} \\
(0.930)\end{array}$ & $\begin{array}{l}-0.32^{\mathrm{d}} \\
(0.788)\end{array}$ \\
\hline $\begin{array}{l}\text { Participation in the IAW involves high investments for } \\
\text { the implementation of the various animal } \\
\text { welfare criteria. }{ }^{* * *}\end{array}$ & $\begin{array}{c}1.23^{\mathrm{abc}} \\
0.807\end{array}$ & $\begin{array}{l}0.53^{\mathrm{d}} \\
(1.052)\end{array}$ & $\begin{array}{c}0.57^{\mathrm{d}} \\
(0.931)\end{array}$ & $\begin{array}{c}0.43^{\mathrm{d}} \\
(0.772)\end{array}$ \\
\hline $\begin{array}{l}\text { Participation in the IAW is associated with high } \\
\text { additional labor costs. }\end{array}$ & $\begin{array}{l}1.25^{\mathrm{abc}} \\
(0.776)\end{array}$ & $\begin{array}{l}-0.02^{\mathrm{d}} \\
(1.080)\end{array}$ & $\begin{array}{c}0.23^{\mathrm{d}} \\
(1.112)\end{array}$ & $\begin{array}{l}-0.17^{\mathrm{d}} \\
(0.914)\end{array}$ \\
\hline $\begin{array}{l}\text { Participation in the IAW is associated with high } \\
\text { additional costs for the certification. }\end{array}$ & $\begin{array}{l}1.29 \mathrm{abc} \\
(0.776)\end{array}$ & $\begin{array}{l}0.49^{\mathrm{d}} \\
(0.960)\end{array}$ & $\begin{array}{c}0.66^{\mathrm{d}} \\
(0.959)\end{array}$ & $\begin{array}{l}0.32^{\mathrm{d}} \\
(0.956)\end{array}$ \\
\hline $\begin{array}{l}\text { Participation in the IAW means a high expenditure of } \\
\text { time for the daily work in the stable. }{ }^{* * *}\end{array}$ & $\begin{array}{l}1.31^{\mathrm{abc}} \\
(0.729)\end{array}$ & $\begin{array}{c}0.31^{\mathrm{d}} \\
(0.998)\end{array}$ & $\begin{array}{c}0.48^{\mathrm{d}} \\
(1.144)\end{array}$ & $\begin{array}{l}0.00^{\mathrm{d}} \\
(0.832)\end{array}$ \\
\hline
\end{tabular}


Table 2. Cont.

\begin{tabular}{|c|c|c|c|c|}
\hline Factor and Statements & $\begin{array}{l}\text { Cluster D } \\
(n=52)\end{array}$ & $\begin{array}{c}\text { Cluster A } \\
(n=55)\end{array}$ & $\begin{array}{l}\text { Cluster B } \\
(n=56)\end{array}$ & $\begin{array}{l}\text { Cluster C } \\
(n=53)\end{array}$ \\
\hline $\begin{array}{l}\text { Participation in the IAW means a high expenditure of } \\
\text { time for the documentation. }\end{array}$ & $\begin{array}{l}1.63^{\text {ac }} \\
(0.561)\end{array}$ & $\begin{array}{l}0.58^{\mathrm{bd}} \\
(0.956)\end{array}$ & $\begin{array}{l}1.30^{\mathrm{ac}} \\
(0.807)\end{array}$ & $\begin{array}{l}0.72^{\mathrm{bd}} \\
(0.818)\end{array}$ \\
\hline $\begin{array}{l}\text { Participation in the IAW involves } \\
\text { time-consuming controls. }\end{array}$ & $\begin{array}{l}1.71 \mathrm{abc} \\
(0.457)\end{array}$ & $\begin{array}{l}0.71^{\text {bcd }} \\
(0.956)\end{array}$ & $\begin{array}{l}1.36^{\text {acd }} \\
(0.672)\end{array}$ & $\begin{array}{c}0.17^{\mathrm{abd}} \\
(0.802)\end{array}$ \\
\hline Unannounced controls $* * *$ & $\begin{array}{l}0.22^{b c} \\
(0.608)\end{array}$ & $\begin{array}{l}0.24^{\mathrm{bc}} \\
(0.742)\end{array}$ & $\begin{array}{l}0.74 \text { acd } \\
(0.634)\end{array}$ & $\begin{array}{c}-1.16^{\text {abd }} \\
(0.772)\end{array}$ \\
\hline $\begin{array}{l}\text { Participation in the IAW causes additional stress due to } \\
\text { unannounced controls. }\end{array}$ & $\begin{array}{l}1.42^{c} \\
(0.776)\end{array}$ & $\begin{array}{l}1.04^{\mathrm{bc}} \\
(0.922)\end{array}$ & $\begin{array}{l}1.61^{\text {ac }} \\
(0.528)\end{array}$ & $\begin{array}{c}-0.36^{\mathrm{abd}} \\
(0.901)\end{array}$ \\
\hline $\begin{array}{l}\text { Participation in the IAW bears the risk of being exposed } \\
\text { to additional stress because unannounced controls must } \\
\text { always be expected. }\end{array}$ & $\begin{array}{c}1.37^{c} \\
(0.658)\end{array}$ & $\begin{array}{l}1.11^{\mathrm{c}} \\
(0.832)\end{array}$ & $\begin{array}{l}1.48^{\mathrm{c}} \\
(0.632)\end{array}$ & $\begin{array}{c}-0.28 \text { abd } \\
(0.841)\end{array}$ \\
\hline Perceived public pressure ${ }^{* * *}$ & $\begin{array}{c}-0.64^{\mathrm{abc}} \\
(0.920)\end{array}$ & $\begin{array}{l}0.42^{\mathrm{cd}} \\
(0.901)\end{array}$ & $\begin{array}{c}0.31^{\mathrm{d}} \\
(0.779)\end{array}$ & $\begin{array}{l}-0.06^{\mathrm{d}} \\
(0.907)\end{array}$ \\
\hline $\begin{array}{l}\text { I feel pressure from politicians to improve the housing } \\
\text { conditions in my pigsty. }\end{array}$ & $\begin{array}{l}0.21^{\mathrm{ab}} \\
(1.054)\end{array}$ & $\begin{array}{c}0.85^{\mathrm{d}} \\
(1.008)\end{array}$ & $\begin{array}{l}1.05^{\mathrm{cd}} \\
(0.883)\end{array}$ & $\begin{array}{c}0.49^{\mathrm{b}} \\
(1.049)\end{array}$ \\
\hline $\begin{array}{l}\text { I feel pressure from the media to improve the housing } \\
\text { conditions in my pigsty. }\end{array}$ & $\begin{array}{l}0.27^{\mathrm{ab}} \\
(1.140)\end{array}$ & $\begin{array}{l}1.24^{\mathrm{cd}} \\
(1.018)\end{array}$ & $\begin{array}{l}1.36^{\mathrm{cd}} \\
(0.883)\end{array}$ & $\begin{array}{l}0.68^{\mathrm{ab}} \\
(1.105)\end{array}$ \\
\hline
\end{tabular}

Significance level at ${ }^{*} p \leq 0.05$; ${ }^{* *} p \leq 0.01$; ${ }^{* * *} p \leq 0.001$; ns $p \geq 0.05$ (not significant); letters (a-d) signify a significant difference to the corresponding cluster (Tamhane post-hoc multiple comparison test at significance level 0.05). Numbers without brackets show mean values, numbers in brackets illustrate the items' standard derivations. All statements were scored with a scale from $-2=$ "totally disagree" to $+2=$ "totally agree". $\mathrm{N}=216$.

The first cluster (cluster D) contains 52 pig farmers. It is characterized by an overall highly critical to rejecting attitude towards IAW participation and will therefore be entitled as "initiative animal welfare defeatists". On the one hand, they are of the opinion that additional time required for participation is not appropriately remunerated $(\mu=-1.02 ; \sigma=0.727)$ and, on the other hand, that additional stress associated with participation is not adequately compensated $(\mu=-1.12 ; \sigma=0.732)$. Furthermore, cluster D is distrustful of the IAW, especially when it comes to statements about whether the IAW takes the needs and wishes of farmers into account when remunerating the various farm animal welfare criteria $(\mu=-0.78 ; \sigma=0.825)$ or additional documentation requirements $(\mu=-0.67 ; \sigma=0.834)$. Farmers tend to agree with the statement that participation in the IAW improves the housing conditions of the animals $(\mu=0.40 ; \sigma=0.721)$, while they tend to disagree with the statement that participation improves the performance of the animals $(\mu=-0.12 ; \sigma=0.704)$. Farmers of cluster $\mathrm{D}$ agree without exception with all statements that refer to an increased workload due to IAW participation, but most strongly with statements that participation means additional expenditure of time for documentation $(\mu=1.63 ; \sigma=0.561)$ and includes time-consuming controls $(\mu=1.71 ; \sigma=0.457)$. In addition, they are dismissive of the IAW's unannounced controls. They support the statement that IAW participation causes additional stress due to unannounced controls $(\mu=1.42 ; \sigma=0.776)$ and that participation is associated with additional stress, since unannounced controls must always be expected $(\mu=1.37$; $\sigma=0.658)$. Furthermore, they sense more pressure from the media $(\mu=0.90 ; \sigma=1.140)$ than from politics $(\mu=0.21 ; \sigma=1.054)$ to improve housing conditions in their pigsties. Compared to clusters $\mathrm{A}, \mathrm{B}$, and $C$, farmers in cluster D consider participation in the IAW to have the least economic benefit. At the same time, they estimate the effort involved to be the highest compared to the other clusters. The results of the cluster analysis demonstrate that within certain statements, there occur relatively high standard deviations. This is an indication that there exist heterogeneous settings in the individual groups.

The second cluster (cluster A) includes 55 pig farmers. It is characterized by a clearly critical assessment of possible economic benefits. Farmers in this cluster are declared as "initiative animal welfare critics". They are very critical of possible economic benefits when it comes to ensuring that IAW 
participation is adequately remunerated. This applies in particular to the appropriate compensation for additional stress incurred by the farmer $(\mu=-0.95 ; \sigma=0.756)$ and the perceived cost-benefit ratio $(\mu=-0.82 ; \sigma=0.976)$. Furthermore, cluster A does not assume that the IAW takes into account farmers' wishes and needs during controls $(\mu=-0.40 ; \sigma=1.011)$ and when determining the remuneration $(\mu=-0.31 ; \sigma=0.979)$. With regard to animal benefits, the farmers in cluster A show no to few effects from their IAW participation. This primarily concerns possible improvements of the health $(\mu=-0.40$; $\sigma=0.894)$ and performance of the animals $(\mu=-0.49 ; \sigma=0.814)$. The attitudes of farmers in cluster A differ significantly from those in clusters $B$ and $C$ in terms of the animal benefits. In addition, farmers of cluster A consider participation in the IAW too much of an effort. This is also reflected above all in the additional time required for documentation requirements $(\mu=0.58 ; \sigma=0.956)$ and time-consuming controls $(\mu=0.71 ; \sigma=0.956)$. With regard to additional labor costs, cluster A is roughly indifferent $(\mu=-0.02 ; \sigma=1.080)$. In addition, farmers in cluster A are highly critical of the IAW's unannounced controls. They support the statement that IAW participation causes additional stress due to the unannounced controls $(\mu=1.04 ; \sigma=0.922)$ and that participation is associated with additional stress, since an unannounced control must always be expected $(\mu=1.11 ; \sigma=0.832)$. In principle, farmers from cluster A feel that they are under public pressure to improve housing conditions in their pigsties. This public pressure is perceived both by politicians $(\mu=0.85 ; \sigma=1.018)$ and by the media ( $\mu=1.24 ; \sigma=1.018$ ). Compared to clusters B, C, and D, cluster A sees the lowest benefit for animals by participating in the IAW.

The 56 farmers in the third cluster (cluster B) can be described as "utilitarian", because they are very keen on the practical and personal benefit of participation. Their indecisiveness is particularly evident in the fact that on the one hand, they attach great importance to the advantages of participation, but on the other hand, also to the effort involved. The farmers in cluster B state that IAW participation offers additional financial benefits for the farm $(\mu=1.07 ; \sigma=0.912)$ and that the additional remuneration of the IAW could stabilize the farm's income situation in case of bad pig prices $(\mu=1.07 ; \sigma=0.783$ ). With regard to statements on whether the IAW takes farmers' wishes and needs into account, the skeptical indecisiveness of cluster $B$ is once again apparent, for example, in the question of the AWP's design $(\mu=-0.16 ; \sigma=0.781)$ and the remuneration payments $(\mu=-0.23 ; \sigma=0.914)$. They perceive animal benefits primarily in improvements in housing conditions $(\mu=0.91 ; \sigma=0.880)$ and farm animal welfare $(\mu=0.96 ; \sigma=0.808)$. In contrast to the positive perceptions of the economic benefits and advantages for the animals in case of IAW participation, farmers of cluster B are highly critical of effort, unannounced controls, and perceived public pressure. They consider the highest efforts of participation, on the one hand, in additional documentation requirements $(\mu=1.30 ; \sigma=0.807)$, on the other hand, in time-consuming controls $(\mu=1.36 ; \sigma=0.672)$. Overall, they show a very critical attitude towards unannounced controls $(\mu=1.61 ; \sigma=0.528)$. The same applies to the perceived public pressure to improve the housing conditions in pigsties, both from the political side $(\mu=1.05 ; \sigma=0883)$ and from the media $(\mu=1.36 ; \sigma=0883$ ). Compared to clusters $A, C$, and $D$, they regard economic benefits as the highest, but the expected costs, unannounced controls, and the perceived public pressure to improve housing conditions in the pigsty as the most critical.

A total of 53 farmers could be assigned to cluster C. Since farmers of this cluster attribute a comparatively high economic benefit to IAW participation and do not overestimate the effort involved, the farmers of this cluster are referred to as "initiative animal welfare proponents". While they indicate that participation in the IAW provides additional financial benefits for the farm $(\mu=0.96 ; \sigma=0.831)$, they are more divided on the appropriate level of remuneration $(\mu=0.06 ; \sigma=0.969)$. In terms of trust in the IAW, cluster $\mathrm{C}$ appears indecisive to indifferent. This becomes evident in statements on the perceived consideration of farmers' wishes and needs during controls $(\mu=0.09 ; \sigma=0.815)$ as well as in the design of the AWP $(\mu=-0.06 ; \sigma=0.908)$. Furthermore, cluster $C$ expects that IAW participation will result in improvements in both housing conditions in the pigsties $(\mu=0.98 ; \sigma=0.820)$ and farm animal welfare $(\mu=1.00 ; \sigma=0.809)$. The expected effort reveals mixed results. While additional expenditures for fulfilling documentation requirements $(\mu=0.72 ; \sigma=0.818)$ is estimated to be high, farmers do not 
indicate a significantly increased time expenditure for the daily work in the pigsty $(\mu=0.00 ; \sigma=0.832$ ). Unannounced controls $(\mu=-0.36 ; \sigma=0.901)$, as well as the fact that unannounced controls must always be expected $(\mu=-0.28 ; \sigma=0.841)$, do not appear to be causing the farmers of cluster $C$ too much of a burden. Public pressure is perceived both by politicians $(\mu=0.49 ; \sigma=1.049)$ and by the media $(\mu=0.68 ; \sigma=1.105)$. Compared to clusters $\mathrm{A}, \mathrm{B}$, and $\mathrm{D}$, farmers in cluster $\mathrm{C}$ rate animal benefits resulting from IAW participation the highest. At the same time, they evaluate the expected effort and unannounced controls as the least burdensome compared to the other clusters.

Table 3 shows some characteristics in the clusters analyzed. However, most of the differences between them are not at significant levels. Genders and ages are relatively evenly distributed among the clusters. It is noticeable that cluster B has the largest number of IAW participants at a significant level, while the distribution in cluster A is relatively balanced. At the same time, farmers in cluster B and $\mathrm{D}$ have the least hectares of land, but not at a significant level. Furthermore, it becomes apparent that cluster $C$ includes most of the farmers in a secondary occupation. Overall, farmers in cluster A have the highest average number of fattening pigs. However, it must be emphasized again that the results do not show significant differences between the clusters. A figure of 36.4 percent of farmers from cluster A have participated in the IAW since the first round of the IAW in 2015 and 36.4 percent do not participate in any AWP at all. A figure of 75 percent of cluster B have also participated since the first round of the IAW in 2015, compared to 49.1 percent from cluster C. A figure of 26.4 percent of farmers from cluster C do not participate in any AWP. The share of farmers from cluster D who have participated since the first round of the IAW is at 38.5 percent, but 23.1 percent of this cluster do not participate in any AWP. Significant differences between the individual clusters can be identified regarding the intention to participate. Especially cluster $B(\mu=1.29 ; \sigma=0.78)$ and $C(\mu=1.19 ; \sigma=0.76)$ consider IAW participation as useful. None of the clusters explicitly states that they are not willing to participate in the IAW. Cluster B $(\mu=1.41 ; \sigma=0.85)$ and $C(\mu=1.21 ; \sigma=1.04)$ strongly agreed to the statement whether (also) in the future it was intended to participate in the IAW, while even the rather critical clusters $\mathrm{A}(\mu=0.31 ; \sigma=1.29)$ and $\mathrm{D}(\mu=0.29 ; \sigma=1.24)$ did not reject this statement, although higher standard deviations are apparent in these cases. The participants were also questioned about the profitability of their own farm. All farmers agreed that they were satisfied with their overall economic situation. No significant differences in the level of equity formation or profit generation were found, and the level of net income from operating activities did not show any significant differences.

Table 3. Sociodemographic and farm characteristics of the clusters.

\begin{tabular}{|c|c|c|c|c|}
\hline & $\begin{array}{l}\text { Cluster D } \\
(n=52)\end{array}$ & $\begin{array}{l}\text { Cluster A } \\
(n=55)\end{array}$ & $\begin{array}{l}\text { Cluster B } \\
(n=56)\end{array}$ & $\begin{array}{l}\text { Cluster C } \\
(n=53)\end{array}$ \\
\hline Gender male (female) ${ }^{1}[\%]^{n s}$ & $\begin{array}{l}96.2 \\
(3.8)\end{array}$ & $\begin{array}{c}89.1 \\
(10.9)\end{array}$ & $\begin{array}{l}91.1 \\
(8.9)\end{array}$ & $\begin{array}{l}92.5 \\
(7.5)\end{array}$ \\
\hline Age $^{1} \varnothing^{\text {ns }}$ & 48 & 46 & 44 & 44 \\
\hline Participation (non-participation) $\left.{ }^{1}[\%]\right]^{* *}$ & $\begin{array}{c}61.5 \\
(38.5)^{b}\end{array}$ & $\begin{array}{c}54.5 \\
(45.5)^{\mathrm{b}}\end{array}$ & $\begin{array}{c}87.5 \\
(12.5)^{\mathrm{ad}}\end{array}$ & $\begin{array}{c}67.9 \\
(32.1)\end{array}$ \\
\hline Hectares ${ }^{1} \varnothing^{\mathrm{ns}}$ & 156.44 & 254.95 & 151.91 & 227.92 \\
\hline Main occupation (secondary occupation) ${ }^{1 * *}$ & $50(2)$ & $55(0)$ & $53(3)$ & $45(8)$ \\
\hline Fattening pigs ${ }^{1} \varnothing^{\mathrm{ns}}$ & 1896.65 & 2259.00 & 2028.86 & 2008.70 \\
\hline \multicolumn{5}{|l|}{ Participation $1 * *[\%]$} \\
\hline $\begin{array}{l}\text { I have been participating in the IAW since the second } \\
\text { round in } 2018 .\end{array}$ & 23.1 & 18.2 & 12.5 & 18.9 \\
\hline $\begin{array}{l}\text { I have been participating in the IAW since the first } \\
\text { round from } 2015 \text { to } 2017 \text {. }\end{array}$ & 38.5 & 36.4 & $75.0^{\text {acd }}$ & 49.1 \\
\hline
\end{tabular}


Table 3. Cont.

\begin{tabular}{|c|c|c|c|c|}
\hline & $\begin{array}{l}\text { Cluster D } \\
(n=52)\end{array}$ & $\begin{array}{c}\text { Cluster A } \\
(n=55)\end{array}$ & $\begin{array}{l}\text { Cluster B } \\
(n=56)\end{array}$ & $\begin{array}{l}\text { Cluster C } \\
(n=53)\end{array}$ \\
\hline $\begin{array}{l}\text { I participated in the first round (until 2017) of the } \\
\text { IAW, but I am no longer participating. }\end{array}$ & 7.7 & 5.5 & 0.0 & 3.8 \\
\hline I am participating in another AWP. & 7.7 & 3.6 & 0.0 & 1.9 \\
\hline I do not participate in any AWP. & 23.1 & $36.4^{\mathrm{b}}$ & 12.5 & 26.4 \\
\hline \multicolumn{5}{|l|}{ Intention to participate ${ }^{2}$} \\
\hline $\begin{array}{l}\text { I consider participation in the IAW to be useful. } \\
\qquad * * *[\mu(\sigma)]\end{array}$ & $\begin{array}{c}0.31 \\
(0.98)^{b c}\end{array}$ & $\begin{array}{c}0.25 \\
(1.11)^{\mathrm{bc}}\end{array}$ & $\begin{array}{l}1.29 \\
(0.78)^{\mathrm{ad}}\end{array}$ & $\begin{array}{c}1.19 \\
(0.76)^{\mathrm{ad}}\end{array}$ \\
\hline I am not willing to participate in the IAW. ${ }^{* * *}[\mu(\sigma)]$ & $\begin{array}{c}-0.23 \\
(1.18)^{b}\end{array}$ & $\begin{array}{c}0.20 \\
(1.42)^{\mathrm{bc}}\end{array}$ & $\begin{array}{l}-1.29 \\
(1.14)^{\mathrm{ad}}\end{array}$ & $\begin{array}{c}-0.70 \\
(1.54)^{\mathrm{a}}\end{array}$ \\
\hline $\begin{array}{l}\text { I intend to participate in the IAW (also) in the future. } \\
\qquad * * *[\mu(\sigma)]\end{array}$ & $\begin{array}{c}0.29 \\
(1.24)^{b c}\end{array}$ & $\begin{array}{c}0.31 \\
(1.29)^{b c}\end{array}$ & $\begin{array}{c}1.41 \\
(0.85)^{\text {ad }}\end{array}$ & $\begin{array}{c}1.21 \\
(1.04)^{\text {ad }}\end{array}$ \\
\hline
\end{tabular}

Letters (a-d) demonstrate a significant difference to the corresponding cluster. Level of significance: ${ }^{*}=p \leq 0.05$,

${ }^{* *}=p \leq 0.01,{ }^{* * *}=p \leq 0.001,{ }^{\text {ns }}=$ not significant. ${ }^{1}$ Chi-square test according to Pearson. Pairwise comparison using Bonferroni correction. ${ }^{2}$ These statements were scored with a scale from $-2=$ "totally disagree" to $+2=$ "totally agree". Tamhane post hoc multiple comparisons tests at significance level 0.05.

\section{Discussion and Conclusions}

In this study, the data of 219 farmers who participated in an online survey on their attitudes towards the IAW were analyzed. By applying a cluster analysis with a factor analysis in advance, four clusters of farmers could be formed. Cluster A ("initiative animal welfare critics") is characterized by skepticism towards participation in the IAW. They do not perceive significant benefits for their livestock and associate participation with stress caused by time-consuming and unannounced controls. Cluster B ("utilitarian") shows divided attitudes: on the one hand, they ascribe the highest approval to economic benefits, on the other hand, they are the most likely to be exposed to additional stress through unannounced controls and public pressure. Cluster C ("initiative animal welfare proponents") anticipates the highest animal benefits in case of participation, and compared to the other clusters, the least effort and least additional stress due to unannounced controls. Cluster D ("initiative animal welfare defeatists"), however, displays the strongest distrust of the IAW, disagrees with an economic benefit of participation, and combines participation with the highest effort compared to the other clusters. Cluster $C$ shows a significantly high proportion of part-time farms compared to the other clusters. Recent scientific findings indicate that the economic pressure is often greater for full-time farms than for part-time farms. This could imply a possible correlation to the fact that farmers in cluster $C$ consider the effort to be rather less in comparison to the other clusters [33].

Economic benefit is defined as the degree to which an individual believes that the use of the system, in this case the IAW, is of financial advantage. While clusters B and C see a high economic value in IAW participation, especially by stabilizing farm income in an event of a poor pig price, clusters A and D perceive the economic advantage as insufficient; this is particularly evident in the statements on the appropriate remuneration of farm animal welfare criteria and the emerging stress for the farmer. Previous studies showed that economic motives play an important role in explaining decisions such as an adaptation of systems like AWPs [33]. The expected financial performance represents a significant positive impact on the adoption of sustainable practices in agriculture [34]. Nevertheless, the farmers surveyed all stated without exception that they were satisfied with the economic situation of their farm. This implies that participation in AWPs does not always necessarily have to be associated with economic added value [35].

It is noticeable that attitudes towards trust in the IAW vary, from slightly positive as in cluster C to moderately negative as in cluster $\mathrm{D}$. This applied in particular to the payment of remunerations for the implementation of farm animal welfare criteria. Cluster D shows the greatest distrust of the 
IAW. Nevertheless, clusters A and B also tend to exhibit a slight skepticism regarding trust in the IAW. Consensus regarding this skepticism is that all clusters, albeit to varying degrees, are of the opinion that the IAW is not considering wishes and needs of farmers when it comes to additional documentation requirements. However, it is of utmost importance for a long-term successful implementation of AWPs and farm animal welfare measures that farmers, as relevant key players in the value chain of animal products, accept and are convinced by these AWPs [36,37]. Furthermore, the implementation of animal welfare-oriented measures is also related to the extent to which farmers consider the implementation of a certain measure to be important and sensible in order to ensure sustainable livestock farming [33]. Especially at this point, the present results show that the population of farmers cannot be understood as a homogeneous group; four groups of farmers can be distinguished, which differ in their attitudes towards the IAW and their willingness to participate in it (Table 3). The available results show that the needs and wishes of farmers are not sufficiently considered in the case of additional documentation requirements, in the remuneration of operational animal welfare measures, and in controls from their perspective. Similar findings were also found in earlier studies, e.g., on the perception and acceptance of certification systems with minimum requirements within the bounds of German legislation by farmers [38]. This observation thus bears implications for the program's design, namely the importance to build trust independently of the cluster. It is worth mentioning that cluster B has the largest number of active participants despite the unbalanced perception of the IAW's cost-benefit ratio. The willingness to participate in the IAW was relatively strong during the first round of the IAW in 2015. Due to budget restrictions, only 49 percent of farmers who wanted to take part in the first round of the IAW were actually able to participate, while the remaining farmers were put on a waiting list [39]. This could be a further reason why farmers were frustrated that not everyone could participate and their trust suffered. One way to achieve more trust here can be direct involvement of farmers in the AWP's design. This includes open communication with farmers and active search for compromises. This is not yet about participation itself, but rather about trust in the IAW itself. However, since preferences and attitudes are regarded as relatively long-term cognitive orientations, it is questionable whether farmers will be classified in a different cluster in the long run [40]. Nevertheless, economic efficiency must be kept in mind independently of this in order to be able to operate sustainably. If this is no longer the case due to reductions in remuneration, then behavior will change, despite the same attitude. One possible explanation for the fact that trust in the IAW is viewed rather critically overall could be that during the survey period, it just became apparent that the second round of the IAW will remunerate the criteria significantly lower than in the first. This could have had a negative impact on farmers' trust in the IAW.

Animal benefits are defined as the degree of expectation that a person believes that the use of a system, in this case the IAW, is beneficial and provides support and relative benefits to the animals. Many farmers see the improvement of housing conditions as benefit of AWPs [21,41-43]. The individual clusters differ significantly in their attitudes towards animal benefits. Contrary to clusters B and C, clusters A and D declare that they perceive rather little animal benefit from participating in the IAW. The differences are most evident in the perceived animal health and performance of the livestock. Nonetheless, personal motivation and pleasure in improving animal welfare is considered an important motive for participation in AWPs, although it is often suppressed by financial incentives [44,45]. In addition, the care and responsibility for the animals as well as the receipt of the animal health contribute to the personal success feeling [46]. Therefore, it is to be assumed that those factors also affect the participation in AWPs. A concern of farmers is, however, that those higher farm animal welfare standards could quickly become general legal standards, which speaks for them rather against a participation in AWPs [46].

In the context of this article, effort is understood as the expected and actual effort to participate in the IAW. Effort includes both financial and time aspects. Farmers of clusters A, B, and D see a high effort associated with the IAW participation. This effort is mainly reflected in the increase of additional documentation requirements and time-consuming controls. Previous studies show that additional expenditures associated with participation in AWPs is critically evaluated by many farmers. 
This applies in particular to time stress involved in documentation and control checks as well as restrictions in the daily work on the farm [47]. Another study showed that the willingness to participate in AWPs decreases with increasing implementation effort [48]. The results of this cluster analysis show a mixed picture. Cluster $C$, which consists of about two thirds of participants, considers the overall effort only slightly increased. In cluster B, effort is already considered high, but in cluster D, which has the fewest participants, the effort is estimated to be highest. Therefore here, the above-mentioned thesis that the willingness to participate in AWPs decreases with increasing implementation effort can be agreed to. Due to the fact that additional documentation requirements are perceived as a high effort by all clusters, the IAW should start at this point to facilitate documentation. This can be done, for example, by reducing the extent of documentation or with help of digitalization, with which a part of the documentation could be automatized.

Since the second round in 2018, IAW participation requires at least two annual controls of the farm for compliance with the farm animal welfare criteria. The first audit is announced, while the second is an unannounced control [49]. Thus, unannounced controls refer to a farm audit without the farmer's prior knowledge. While farmers in cluster $C$ experience unannounced controls as not overly stressful, the remaining clusters present a very contrary picture. Clusters $\mathrm{A}, \mathrm{B}$, and D are convinced that the unannounced controls themselves mean additional stress, but they feel also exposed to the risk of additional stress, as unannounced controls must always be expected. From farmers' perspective, additional stress and risk of participation will increase due to unannounced control audits introduced in 2018. Failure to pass the control leads to the remuneration not being distributed or the farmer even having to repay it, which means an additional financial risk [50]. In 2018, 959 farms failed the control audits and were therefore no longer entitled for remuneration [15]. The question of a possible compromise is difficult to answer. The purpose of the unannounced controls is to ensure that the farms always work in accordance with the IAW guidelines, which is essential to make the program credible to critical stakeholders and consumers [49]. On the one hand, it is important for the IAW that the farm animal welfare criteria to be remunerated are actually met. Farmers, on the other hand, are concerned that they will lose their independence by participating in AWPs $[4,46,47,49]$. As a compromise, a period of time during which unannounced controls can be expected could be considered. On the downside, this could encourage opportunistic behavior by farmers.

Perceived public pressure refers to pig farmers in relation to their immediate environment, such as friends, colleagues, and family, but also to the image of their own professional field in relation to the indirect environment, such as society and politics. Furthermore, social pressure exerted on farmers by the media and politicians is also perceived as societal pressure, as this could also be a motivation for farmers to participate in AWPs and thus gain meaning for them [51]. Altogether, it is apparent in all clusters, albeit to different extents, that farmers feel pressured by the media and politicians. This effect is most evident in cluster B. The influence of public pressure is also evident in the other clusters, although to a lesser extent. On the basis of the results of the cluster analysis, the effect of the social environment can be clearly seen. A previous study found that issues such as business development, decent agriculture, and the adaptation of nature conservation are linked to social influence. The social environment influences the operational development of the farm to a certain extent [52]. Participation in the IAW can also be seen as a strategic decision for the farm. Another study demonstrates that the media, non-governmental organizations, and politicians in particular are perceived by farmers as pressure groups [53].

Like most non-experimental studies, this study has some limitations that need to be considered when interpreting the results. First of all, the study is not representative because the sample of 219 farmers is very small and the sample composition is different compared to the population of German farmers due to the pre-selection of the survey participants resulting from the distribution channels used and the survey methodology. Farmers in this study operate farms with an average of 195.89 hectares, which is about four times the average of the German farming population. Furthermore, the social desire for social recognition, but also protest, may have led some farmers to indicate a more 
positive or negative attitude towards the IAW than they actually have. These aspects could possibly lead to distortions of the results. A further point of discussion is that within the results, high standard deviations appear sporadically. This is an indication that the farmers' attitudes within the cluster still differ in these individual items. Another point of criticism is the online survey itself. The biggest advantage of an online survey is, on the one hand, that it is easy to implement and to realize. On the other hand, no response rate can be provided with this method, as it is not apparent how many people have received the link via the various mailing lists. Furthermore, the subjective naming of the clusters, which was performed by the authors and therefore is not considered universal, should be mentioned. Nevertheless, this study provides interesting results for the design of AWPs such as the IAW. The more that is known about the attitudes of groups, the more likely it is that they can be targeted.

From the results, it is evident that four factors contribute significantly to the farmers' attitude towards the IAW. These include economic benefits of participation, expected effort including additional documentation requirements and time-consuming and unannounced controls, as well as animal benefits. Based on these factors, three possibilities could be derived to make participation in the IAW more attractive for farmers. Firstly, it appears relevant to provide further financial incentives to attract the attention of the more pessimistic clusters and to increase economic net benefits, especially for pig farmers in clusters A and D. Another advantage of increased financial incentives could be that farmers in clusters A and D could reconsider their attitudes to economic benefits, making participation more probable for them. On the other hand, the IAW has a unique selling proposition, namely that, supported by the food retail sector, a fixed amount per kilogram of meat sold is paid into a budget, which is then used to finance higher farm animal welfare standards [54]. This means that farmers receive a guaranteed fixed sum for farm animal welfare measures implemented, provided that no deficiencies are documented during the controls. Moreover, the financing is independent of the consumers' purchasing behavior. This differentiates the IAW from other AWPs in Germany. Secondly, it appears that the effort involved in participation, especially in terms of additional documentation requirements and unannounced controls, tends to be a deterrent to farmers. This applies to all four clusters. Consequently, it could be implied that a reduction of costs, namely bureaucracy and unannounced controls, could make participation more interesting for farmers, since the expected and actual effort, at least with regard to documentation, would be diminished. Improvements of unannounced controls are more difficult to evaluate, as the IAW aims to gain an authentic impression of the pigsties' housing conditions. Thirdly, it is evident from the results of this study that farmers in clusters A and D do not associate participation in the IAW with any particular benefit for the animals. Thus, another option could be to identify additional target groups by expanding the IAW's criteria catalog to include additional eligible criteria. This could arouse the interest of further farms, not least through possible deadweight effects. Through deadweight effects, farmers who already meet the requirements in their pens may become motivated to participate, so that no structural changes or changes in farm operations are necessary.

The aim of this article was to identify groups of farmers who differ in their attitudes towards the IAW and to analyze these groups. This was achieved by grouping pig farmers into four clusters. These clusters also show differences between their socio-demographic and farm characteristics, although not at a significant level. Based on the results, it is possible to deduce what is relevant for the farmers in each cluster. The most important findings of the study are, on the one hand, that farmers in all clusters face public pressure from politicians and the media, albeit to varying extents. On the other hand, the effort, especially with regard to additional documentation requirements and unannounced controls, is perceived as very demanding, which is in accordance with previous studies $[47,48]$.

Future research could focus on the exact wishes and needs of farmers regarding the possible design of the IAW and its criteria. In addition, it could be scientifically investigated how participation actually affects the working hours spent. One possible method of investigation to make comparisons regarding the financial situation could be work diaries. These results could provide even more detailed information than that obtained in the present study and would therefore yield very interesting business 
management results. Additionally, for the future, farmers' opinions should be considered and compared separately between participants and non-participants in the IAW. For this purpose, choice-based experiments could be used to find out under which conditions farmers would implement which animal welfare measures. Finally, the question should be included in the future to what extent the financing concept might have an impact on the willingness of farmers to participate. Thus, farmers have a financial security for the next three years, independent of the development of the market, which could be important for many. In addition, it would be interesting to investigate how participation in the IAW actually affects animal welfare.

Author Contributions: S.S. was responsible for the conceptualization, investigation, methodology, analysis, validation, writing, editing, and reviewing of the study. L.v.P. was responsible for methodology and validation of the study. H.H. was responsible for methodology, analysis, investigation, writing, editing, and reviewing of the study. All authors have read and agreed to the published version of the manuscript.

Funding: This research was funded by the Federal Ministry of Food and Agriculture, as a part of the INMATI project.

Acknowledgments: We acknowledge support by the Federal Ministry of Food and Agriculture and the German Research Foundation and the Open Access Publication Funds of the Göttingen University.

Conflicts of Interest: The authors declare no conflict of interest.

\section{References}

1. Robbins, J.A.; Franks, B.; Weary, D.M.; von Keyserlingk, M.A. Awareness of ag-gag laws erodes trust in farmers and increases support for animal welfare regulations. Food Policy 2016, 61, 121-125. [CrossRef]

2. Böhm, J.; Kayser, M.; Nowak, B.; Spiller, A. Productivity vs. Naturalness?-The German agriculture and food industry in the Social Web. In The Food Industry in Public_Social Media as a New Challenge for PR, 1st ed.; Kayser, M., Böhm, J., Spiller, A., Eds.; Göttingen Culliver Publishing: Göttingen, Germany, 2010; pp. 105-140.

3. Kayser, M.; Schlieker, K.; Spiller, A. The perception of the term "factory farming" from the perspective of society. Ber. Landwirtsch. Z. Agrarpolit. Landwirtsch. 2012, 90, 417-428. (In German)

4. Bock, B.B.; van Huik, M.M. Animal Welfare: Animal welfare: The attitudes and behaviour of European pig farmers. Br. Food J. 2007, 109, 931-944. [CrossRef]

5. Cembalo, L.; Caracciolo, F.; Lombardi, A.; Del Guidice, T.; Grunert, K.G.; Cicia, G. Determinants of individual attitudes toward animal welfare-friendly food products. J. Agric. Environ. Ethics 2016, 29, 237-254. [CrossRef]

6. Vanhonacker, F.; Verbeke, W. Public and Consumer Policies for Higher Welfare Food Products: Challenges and Opportunities. J. Agric. Environ. Ethics 2014, 27, 153-171. [CrossRef]

7. Lagerkvist, C.J.; Hess, S. A meta-analysis of consumer willingness to pay for farm animal welfare. Eur. Rev. Agric. Econ. 2011, 38, 55-78. [CrossRef]

8. Ingenbleek, P.T.; Immink, V.M.; Spoolder, H.A.; Bokma, M.H.; Keeling, L.J. EU animal welfare policy: Developing a comprehensive policy framework. Food Policy 2012, 37, 690-699. [CrossRef]

9. De Jonge, J.; van der Lans, I.O.; van Trijp, H.C.M. Different shades of grey: Compromise products to encourage animal friendly consumption. Food Qual. Prefer. 2015, 45, 87-99. [CrossRef]

10. Weinrich, R.; Kühl, S.; Franz, A.; Spiller, A. Consumer preferences for high welfare meat in Germany: Self-service counter or service counter? Int. J. Food Syst. Dyn. 2015, 6, 32-49. [CrossRef]

11. Van Loo, E.J.; Caputo, V.; Nayga, R.M.; Verbeke, W. Consumers' valuation of sustainability labels on meat. Food Policy 2014, 49, 137-150. [CrossRef]

12. Heise, H.; Theuvsen, L. The willingness of conventional farmers to participate in animal welfare programs: An empirical study in Germany. Anim. Welf. 2017, 26, 67-81. [CrossRef]

13. Heyder, M.; Theuvsen, L. Determinants and effects of corporate social responsibility in German agribusiness: A PLS model. Agribusiness 2012, 28, 400-428. [CrossRef]

14. Market Balance Livestock and Meat 2020. Available online: https://www.ami-informiert.de/fileadmin/shop/ leseproben/AMI-MarktBilanz_Vieh_Fleisch_2020_IHVZ_.pdf (accessed on 24 October 2020). (In German)

15. Classification and Outlook on the Initiative Animal Welfare 2018. Available online: https://initiativetierwohl.de/wp-content/uploads/2018/05/20180503-ITW-Rechenschaftsbericht.pdf (accessed on 24 April 2020). (In German) 
16. Opinions on Livestock Husbandry and Animal Welfare Labels. Available online: https: //initiative-tierwohl.de/wp-content/uploads/2018/07/Auswertung-Forsa-Umfrage-zur-Nutztierhaltungund-Tierwohlkennzeichnung-Juni-2018.pdf (accessed on 24 April 2020). (In German)

17. Heise, H.; Overbeck, C.; Theuvsen, L. The animal welfare initiative from the point of view of various stakeholders: Evaluations, possibilities for improvement and future developments. Ber. Landwirtsch. Z. Agrarpolit. Landwirtsch. 2017, 95, 1-35. (In German)

18. Hansson, H.; Lagerkvist, C.J. Defining and measuring farmers' attitudes to farm animal welfare. Anim. Welf. 2014, 23, 47-56. [CrossRef]

19. Kaupinnen, T.; Vainio, A.; Valros, A.R.H.; Vesala, K.M. Improving animal welfare: Qualitative and quantitative methodology in the study of farmers' attitudes. Anim. Welf. 2010, 19, 523.

20. Franz, A.; Deimel, I.; Spiller, A. Concerns about animal welfare: A cluster analysis of German pig farmers. Br. Food J. 2012, 114, 1445-1462. [CrossRef]

21. Von Hardenberg, L.; Heise, H. German Pig Farmers' Attitudes towards Animal Welfare Programs and their Willingness to Participate in these Programs. An Empirical Study. Int. J. Food Syst. Dyn. 2018, 9, $289-301$. [CrossRef]

22. Venkatesh, V.; Thong, J.; Xu, X. Unified Theory of Acceptance and Use of Technology: A Synthesis on the Road Ahead. J. Assoc. Inf. Syst. 2016, 17, 328-376. [CrossRef]

23. Von Hardenberg, L.; Heise, H. Factors influencing the willingness of German butcher shops and direct marketers to offer animal welfare meat-A PLS analysis. In Proceedings of the German Association of Agricultural Economists (Gewisola), Halle/Saale, Germany, 18 September 2020. [CrossRef]

24. Diaz-Bone, R.; Weischer, C. Lexicon of Methods for the Social Sciences, 1st ed.; Springer: Wiesbaden, Germany, 2015. (In German)

25. Kaiser, H.F.; Rice, J. Little Jiffy, Mark Iv. Educ. Psychol. Meas. 1974, 34, 111-117. [CrossRef]

26. Backhaus, K.; Erichson, B.; Plinke, W.; Weiber, R. Multivariate Analysis Methods. An Application-Oriented Introduction, 14th ed.; Springer Gabler: Berlin, Germany, 2016.

27. Bühl, A. SPSS 18 Introduction to Modern Data Analysis, 12th ed.; Person: Munich, Germany, 2008. (In German)

28. Brosius, F. SPSS 19, 1st ed.; MITP: Munich, Germany, 2011. (In German)

29. Hair, J.; Anderson, R.E.; Tatham, R.L. Multivariate Data Analysis, 7th ed.; Pearson: London, UK, 2013.

30. Annually Situation Report of the German Farmers' Association. Available online: https://www. bauernverband.de/situationsbericht/3-agrarstruktur/35-arbeitskraefte-und-auszubildende (accessed on 24 April 2020). (In German)

31. Agriculture, Forestry and Fisheries-Livestock Production on Farms-Agricultural Structure Survey. Available online: https:/www.destatis.de/DE/Themen/Branchen-Unternehmen/LandwirtschaftForstwirtschaft-Fischerei/Tiere-Tierische-Erzeugung/Publikationen/Downloads-Tiere-und-tierischeErzeugung/viehhaltung-2030213169004.pdf?_blob=publicationFile (accessed on 24 April 2020). (In German)

32. Facts and Figures-Agriculture, Forestry and Food Industry with Fishing and Viticulture and Horticulture. Available online: https:/www.bmel.de/SharedDocs/Downloads/Broschueren/DatenundFakten.pdf?_blob= publicationFile (accessed on 24 April 2020). (In German).

33. Schröter, I.; Mergenthaler, M. Assessment of operational measures for animal welfare oriented agricultural animal husbandry of the future by farmers in Germany, taking into account personal characteristics. In Proceedings of the German Association of Agricultural Economists (Gewisola), Halle/Saale, Germany, 23 September 2020. (In German)

34. Trujillo-Barrera, A.; Pennings, J.M.E.; Hofenk, D. Understanding producers' motives for adopting sustainable practices: The role of expected rewards, risk perception and risk tolerance. Eur. Rev. Agric. Econ. 2016, 43, 359-382. [CrossRef]

35. Heise, H.; Schwarze, S.; Theuvsen, L. Economic effects of participation in animal welfare programs: Does it pay off for farmers? Anim. Welf. 2018, 27, 167-179. [CrossRef]

36. Franz, A.; Meyer, M.; Spiller, A. Introduction of an Animal Welfare Label in Germany: Results of a stakeholder survey. Yearb. Austrian Soc. Agric. Econ. 2010, 19, 41-50.

37. Gulbrandsen, L.H. Creating markets for eco-labelling: Are consumers insignificant? Int. J. Consum. Stud. 2006, 5, 477-489. [CrossRef] 
38. Jahn, G.; Peupert, M.; Spiller, A. Attitudes of German Farmers towards the QS System: Results of a First Exploratory Study; Working paper; Institute of Agricultural Economics, University of Göttingen: Göttingen, Germany, 2003.

39. Only $46 \%$ of the Registered Farms Receive a Commitment for the Initiative Animal Welfare! Available online: https://www.topagrar.com/management-und-politik/news/nur-46-der-registrierten-betriebe-erhaltenzusage-fuer-initiative-tierwohl-9433297.html (accessed on 7 August 2019). (In German)

40. Weber, H.; Rammsayer, T. Handbook of Personality Psychology and Differential Psychology; Hogrefe: Göttingen, Germany, 2005. (In German)

41. Hubbard, C.; Bourlakis, M.; Garrod, G. Pig in the middle: Farmers and the delivery of farm animal welfare standards. Br. Food J. 2007, 109, 919-930. [CrossRef]

42. Hubbard, C. Do farm assurance schemes make a difference to animal welfare? Vet Rec. 2012, 170, $150-151$. [CrossRef]

43. Skarstad, G.A.; Terragni, L.; Torjusen, H. Animal Welfare according to Norwegian Consumers and Producers: Definitions and Implications. Int. J. Sociol. Food Agric. 2007, 15, 74-90.

44. Mergenthaler, M.; Schröter, I. Market failures in supplying animal welfare: Some conceptual thoughts for future research. In Proceedings of the 13th International European Forum on System Dynamics and Innovation in Food Networks, Garmisch-Partenkirchen, Germany, 18 February 2019. [CrossRef]

45. Rode, J.; Gómez-Baggethun, E.; Krause, T. Motivation crowding by economic incentives in conservation policy: A review of the empirical evidence. Ecol. Econ. 2015, 117, 270-282. [CrossRef]

46. Wildtraut, C.; Mergenthaler, M. Further Development of Agricultural Animal Production Methods for More Animal Welfare from the Perspective of Livestock Farmers—Results from Moderated Group Discussions; SocialLab: Brussels, Belgium, 2018; pp. 197-203. (In German)

47. Kjærnes, U.; Miele, M.; Roex, J. Attitudes of Consumers, Retailers and Producers to Farm Animal Welfare, 2nd ed.; Welfare Quality Reports; UWP: Wales, UK, 2007; pp. 1-183.

48. Latacz-Lohmann, U.; Schreiner, J.A. Assessing Consumer and Producer Preferences for Animal Welfare Using a Common Elicitation Format. J. Agric. Econ. 2019, 70, 293-315. [CrossRef]

49. Auditors and Certification Authorities. Available online: https://initiative-tierwohl.de/partner/auditorenund-zertifizierungsstellen/ (accessed on 24 October 2020). (In German)

50. Initiative Animal Welfare: New Round from January 2018. Available online: https://www.agrarheute.com/ landundforst/betrieb-familie/betriebsfuehrung/initiative-tierwohl-neue-runde-ab-januar-2018-536760 (accessed on 24 October 2020). (In German)

51. Heise, H. Animal Welfare in Livestock Farming: Importance and Feasibility of Various Animal Welfare Measures from the Perspective of German Farmers. A Stakeholder Analysis. Ph.D. Thesis, University of Göttingen, Göttingen, Germany, 30 January 2017. (In German).

52. Kuczera, C. The Influence of the Social Environment on Farm Decisions of Farmers; Margraf Publishers: Weikersheim, Germany, 2006; pp. 56-171. (In German)

53. Ermann, M.; Christoph-Schulz, I.; Spiller, A. Under Pressure-How do farmers in Germany perceive the pressure from external stakeholders? Yearb. Austrian Soc. Agric. Econ. 2017, 26, 85-94.

54. Animal Welfare Initiative-Here's How It Works. Available online: https://initiative-tierwohl.de/verbraucher/ so-funktioniert-s/ (accessed on 24 April 2020). (In German)

Publisher's Note: MDPI stays neutral with regard to jurisdictional claims in published maps and institutional affiliations.

(C) 2020 by the authors. Licensee MDPI, Basel, Switzerland. This article is an open access article distributed under the terms and conditions of the Creative Commons Attribution (CC BY) license (http://creativecommons.org/licenses/by/4.0/). 